\title{
FATWA MAJELIS ULAMA INDONESIA (MUI): On Ahmadiyah
}

\author{
By: Khoiruddin Nasution*
}

\begin{abstract}
In the end of 2007 and the beginning of 2008, the Ahmadiyah again became an important issue in Indonesia. Similar issue appeared in 1980 and produced a fatwa on it by the Council of Indonesian Ulama. This short paper describes the basic reason why the majority of Muslims in Indonesia oppose the existence of the Ahmadiyah. To analyze the problem, the theory of clustering Islamic teachings is used. Nasr Hamid Abu Zaid, for example, divides Islamic teachings into three levels; the original text of Islam, interpretation, and the teachings practiced by Muslims. Similar theory is formulated by Abdullah Saeed. The result is that the basic reason of the opposition of Indonesian Muslim to the existence of the Ahmadiyah is its belief of the status of Mirza Ghulam Ahmad as a prophet whereas according to the belief of majority Muslim, Muhammad is the last prophet. Therefore, the best way to solve the problem is a declaration or a recognition that Ahmadiyah is out of Islam. This solution has been offered by the Minister of Religious Affairs of Indonesia.
\end{abstract}

बैทे 1980 ơrn db.

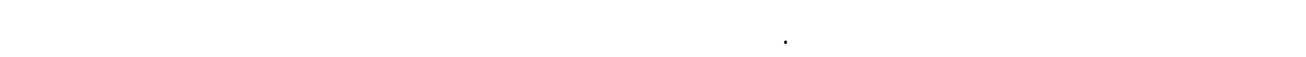

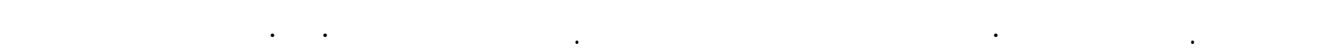

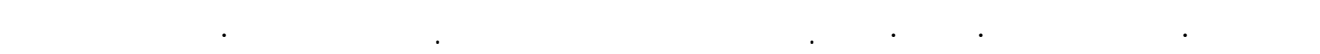
世 Ḱğ

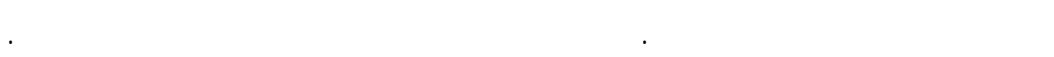

Keywords: fatwa, MUI, and Ahmadiyah

\section{A. Introduction}

In the end of 2007 the Ahmadiyah case emerged and resulted anarchy in many areas in Indonesia, such as Bogor, Mataram (West Nusa Tenggara), and Sadasari, the sub-district of Argapura Majalengka Jawa Barat. As a result of these anarchy, some of the Ahmadiyah's houses of worship were damaged and the followers lived unsafe life and even threatened. Consequently, the Ahmadiyah community asked the policemen for protection. They came to the headquarters of the policeman on Monday, 7 January 2008. In addition, they instituted a suit to 
the constitutional court. One poin of the suit demands Indonesian to be a democratic-modern nation, tolerant, pluralist, promote equality and protect the minority. ${ }^{1}$

In the effort to get a recognition as well as protection from Indonesian Muslims, the central board of Jemaat Ahmadiyah Indonesia released 12 points of clarification on their teachings to show that they are not deviant. However, these 12 points could not solve the problem. Some Islamic organizations such as MUI, Muhammadiyah, Dewan Dakwah Islam Indonesia, Front Umat Islam, deny Ahmadiyah teaching as a right teaching. In their opinion, the Ahmadiyah is a deviant sect. Some socio-religious organizations constantly urged the government to ban the dissemination of Ahmadiyah teachings throughout Indonesia. In line with this demand, MUI gave three alternate options to the Ahmadiyah community, that is to go back to the right path, to be addressed as non-Muslim, or to be dispersed. ${ }^{2}$

One point to note, the Ahmadiyah case in Indonesia is not a new thing. It emerged in 1980 with the issued fatwa on Ahmadiyyah Qadiyan by the MUI. Besides, the MUI also issued a recommendation in 1984 through national working meeting (Rakernas) suggesting the banning on the dissemination of the Ahmadiyah teachings in Indonesia.

Accordingly, in its seventh national conference (MUNAS) on 26 s/d 29 July 2005 MUI discussed eleven concepts of fatwa; one of which was on Ahmadiyah. As a result of the discussion, these concepts were decreed and compiled in a book entitled 'Fatwa Munas VII Majelis Ulama Indonesia' by the Council of Indonesian Ulama in 2005. These eleven fatwas are: (1) Copyright Fortification (HKI), (2) Shamanism (Kahanah) and Fortune-telling ('Irafah), (3) Communal Prayers, (4) Interreligious Marriage, (5) Interreligious Inheritance, (6) Criteria of

* Permanent instructor at the Faculty of Islamic Jurisprudence (Syari'ah) and Post Graduate program in UIN Sunan Kalijaga Yogyakarta. Non-Permanent Instructor in Master Program (MSI) at Universitas Islam Indonesia UII Yogyakarta, and Master Program of Islamic studies (M.PdI.) at UNU Solo, International program at the Faculty of law at UII Yogyakarta. Email: knasut@yahoo.com.

1 Jawa Pos, Thursday 10 January 2008.

${ }^{2}$ Republika, Friday 18, 19 and 20 January 2008, p. 1. 
Maslahat, (7) Pluralism, Liberalism, and Religious Secularism, (8) Revocation of Proprietary Rights for Public Interests, (9) Female Leader of Prayers, (10) Death Penalty for Particular Criminal Acts, and (11) Ahmadiyah Denomination.

It is clear that the emergence of some Indonesian Muslims demands on the Ahmadiyah is not a new thing. The existance of the Ahmadiyah has become a problem since 1980, at least by the MUI. However, some other Indonesian Muslims has opposed the objection of the former Muslims on the existance of the Ahmadiyah. This short article focuses on the discussion on fatwa on Ahmadiyah, since it gives a significant impact on some Indonesian Muslims' attitude towards the Ahmadiyah community. Nevertheless, before discussing Ahmadiyah denomination, it is necessary to bring forward MUI's fatwa on interreligious community relationship in Indonesia. It is aimed at understanding the context of those fatwas. Therefore, the historicity of the fatwas on interreligious community relationship is described after introduction. The discussion on the fatwas on the Ahmadiyah comes later, especially the reason for and objection of some Indonesian Musims on the denomination. To analyse this problem, a theory on clustering Islamic teachings is used.

\section{B. The Historicity of the MUI's Fatwa on Interreligious Community Relationship}

Before putting forward fatwas on religious community life, both relationship among Muslims and between interreligious community, the way the MUI issues a fatwa is described. It is necessary to evaluate the category of fatwa on interreligious community relationship, since the level of significance is determined by the process of issuance. Some fatwas were issued by the Fatwa Commission, meaning that they were discussed only by a few people. Many other fatwas were results of a number of Indonesian ulama's thoughts in a conference. In order to know the difference among the three products of the MUI, a detail explanation on the process of making fatwa is presented as follow:

Process of making fatwa can be categorized into three, they are:

1. Fatwa issued by the Fatwa Commission of the MUI. 
2. Fatwa issued through a discussion in a conference or in the Ulama Annual Conference held by the MUI. For instance, a fatwa on genital operation, interreligious marriage and the Ahmadiyah were issued in the National Conference in 1980.

3. Fatwa issued through national conference (MUNAS) which is held in every five-year. ${ }^{3}$

MUNAS, the abreviation of Musyawarah Nasional, is the highest consultative forum among the MUI, and is held in every five-year. Beside evaluating the implementation of working program, the determination on the outline of working program for the following period and electing the new board, MUNAS is also a joint forum which responses various problems of the nation. ${ }^{4}$

In principle, the above three ways of issuing a fatwa of the MUI can be concluded into two, they are the fatwa issued by the Fatwa Commission of the MUI and the fatwa issued by a number of Indonesian ulama. The fatwa issued by the Fatwa Commission is produced through a discussion among the member of this commission, where in its first establishment in 1975 consisted of 7 people. So, such a fatwa is a result of thought of the member of the fatwa commission.

The fatwa issued through a conference is a fatwa discussed through annual or five-yearly conference of ulama held by the MUI. For instance, in the 1980 National Conference, the Indonesian ulama issued fatwas on genital operation, inter-religious marriage and the Ahmadiyah. ${ }^{5}$

It is important to note that the establishment of the MUI's fatwa either through the fatwa commission or conference is based on the need or whenever the MUI is asked to respond to one particular problem in Islamic law by either an individual or government. The fatwa issued by the Fatwa Commission is a consequent of the large amount of problems addressed to the MUI. Therefore, it is

\footnotetext{
${ }^{3}$ MUI Team, Fatwa MUNAS VII Majelis Ulama Indonesia, (Jakarta: MUI), p. i.

${ }^{4}$ See the introductory remarks of the leadership board of the Council of Indonesian Ulama on Munas MUI 26-29 July 2005. Ibid.

${ }^{5}$ Mohammad Atho Mudzhar, Fatwa-fatwa Mejelis Ulama Indonesia: Sebuah Studi tentang Pemikiran Hukum Islam di Indonesia, 1975-1988, bilingual edition. (Jakarta: INIS, 1993), pp. 79-80.
} 
impossible for the MUI to solve all the problems only through annual or fiveyearly conference.

In contrast to the above demand, there emerges an assumption from an element of Indonesian Muslim that the MUI issues a fatwa very easily. As a result, the acknowledgement on the authority of the MUI's fatwa (either decree or decision) continues to decrease. In response to this, the MUI and its Fatwa Commission have agreed to limit issuing fatwa since 1986. However, not all of the problems are responded with a fatwa. ${ }^{6}$

Nevertheless, the MUI's fatwas on the relationship among religious community were issued through conferences both annual and five-yearly conference, rather than issued by the Fatwa Commission. It indicates that the fatwa issued on this problem is considered important, since it always be discussed by a number of Indonesian ulama and not merely by the Fatwa Commission.

A number of fatwas have been issued on the relationship among religious community since the establishment of the MUI. Such fatwas can be categorized into two. First is fatwa which covers the relationship among Muslims. Second is fatwa which covers the relationship between Muslim and non-Muslim. Fatwas belong to the first category are:

1. Fatwa on Ahmadiyyah Qadiyan (a result of the second National Conference, 26 May - 1 June 1980)

2. Fatwa on Inkarus Sunnah (decreed on 27 June 1983).

3. Fatwa on Syi 'ah (a result of the national working meeting in March 1984)

4. Fatwa on Darul Arqam (decreed on 13 August 1994)

5. Fatwa on Islam Jama'ah

Meanwhile, the fatwas which belong to the second category are as follow:

1. Fatwa on inter-religious marriage

2. Fatwa on Christmas celebration, decreed on 3 March 1981,

3. Fatwa on preventing the influence of syi'ah teachings in Indonesia in 1984 (decreed through annual conference of the Ulama)

\footnotetext{
${ }^{6}$ Ibid., p. 87.
} 
In 1984, the MUI issued a recommendation that the Indonesian government ban the dissemination of Ahmadiyah in Indonesia through the national working meeting. In total, there have been three decrees of the MUI on Ahmadiyah; two fatwas issued in 1980 and 2005 and one recommendation issued in 1984.

\section{Fatwa on Ahmadiyah}

As mentioned previously, there were two fatwas issued in 1980 and 2005 and one recommendation in 1984. The fatwa on Ahmadiyah in 2005 was one of the eleven fatwas which were discussed through the seventh MUNAS of the MUI held on 26 to 29 July 2005. Dr. KH. MA. Sahal Mahfudh in his forewords stated that these eleven fatwas were based on problems and materials taken from the society through various forums, such as coordination meeting among regions (Rakorda), national working meeting (Rakernas), regional conference (Musda), or even from various letters, telephones, emails addressed to the Council of Indonesian Ulama. This indicates that Ahmadiyah case is one of serious problems in Indonesian Muslims' life.

To see the similarity and difference between the two fatwas in 1980 and 2005 , it is necessary to mention the content of the fatwa. The following is the content of the fatwa decreed in 1980.

The Council of Indonesia Ulama in the second national conference on 11 17 Rajab $1400 \mathrm{H}$ or on 26 May - 1 June 1980 in Jakarta issued a fatwa on Ahmadiyah community as follows:

1. In line with data and facts found in nine books on the Ahmadiyah, the MUI issues a fatwa that the Ahmadiyah is a non-Islamic group, heretical and deviated.

2. Regarding the Ahmadiyah case, the MUI should always be in contact with the government

Then in the national working meeting on $1-4$ Jumadil Akhir $1404 \mathrm{H}$. or on 4 -7 March 1984, the MUI issued a recommendation on the Ahmadiyah community as follows: 
1. That Jamaah Ahmadiyah, in the territory of the Republic of Indonesia, which is a corporation based on the decree of the Ministry of Justice of the Republic of Indonesia No. JA/23/13 on 13 March 1953 (appendix to the state gazette on 31 March 1953 No.26) for the Muslim community has evoked:

a. social unrest since its doctrines are in contrast to Islamic doctrines

b. disintegration, especially in devotional matters (prayer), on marriage and so on

c. threat to the social stability and the nation security.

Based on these reasons, it is hoped that the authority reviews the decree of the Ministry of Justice of the Republic of Indonesia No. JA/23/13 on 31 March 1953 (appendix to the state gazette no. 26, on 31 March 1953)

2. Recommend:

a. That the MUI, the provincial MUI and the local MUI, all ulama, and preachers throughout Indonesia should explain the heretical doctrines of the Ahmadiyah Qadian which is out of Islam.

b. Those who have already joined the Jemaat Ahmadiyah Qadian to return to the Islamic doctrine

c. To all Muslims community to increase their alertness in order not to get influenced by this heretical doctrines. ${ }^{7}$

The decree on fatwa of the Council of Indonesian Ulama on Ahmadiyah teachings in 2005 enlisted in the decree of the MUI No. 11/MUNAS VII/MUI/15/2005. The introduction of the fatwa states that the dissemination of the Ahmadiyah teachings in Indonesia has evoked social unrest. Although there was a fatwa issued through the second national conference of the MUI in 1980 stating Ahmadiyah as heretical sect as well as the banning of their activities

\footnotetext{
${ }^{7}$ Tim Penyunting Majelis Ulama Indonesia, Himpunan Fatwa Majelis Ulama Indonesia, (Jakarta: MUI, 1997), p. 71; Sekretatiat MUI, Himpunan Keputusan dan Fatwa Majelis Ulama Indonesia, (Jakarta: Sekretariat MUI, t.t.), p. 147.
} 
through some decrees issued by regional court, the dissemination of the Ahmadiyah teachings has continued to spread. In this MUNAS (national conference) the MUI was asked to affirm its fatwa on Ahmadiyah and demanded the government to ban the organization and its dissemination nationally.

The decree mentions that the MUI in the seventh National Conference, on 19-22 Jumadil Akhir 1426 H or 26-29 July 2005 M after considering:

a. That up to now the Ahmadiyah denominations continuously make an effort to disseminate their doctrines in Indonesia, although the MUI has issued a fatwa and banned them

b. That the effort to disseminate the Ahmadiyah doctrines has evoked social unrest

c. That some members of the society urged the affirmation of the MUI's fatwa on the Ahmadiyah doctrines in relation with the emergence of various opinions and reactions within the society

d. That in order to comply with the demand of the society and to maintain the purity of Islamic belief, the Council of Indonesian Ulama needs to affirm the fatwa on the Ahmadiyah doctrines

Bearing in Mind:

(1) The Qur'an 33: 40,

"Muhammad is not the father of any of your men, but (he is) the apostle of God, and the seal of the prophets. And God has full knowledge of all things." (al-Ahzab: 40).

The Qur'an 6: 158,

"Verily, this is My way, leading straight: follow it: follow not (other) paths : they will scatter you about from His (great) path : Thus doth he command you that ye may be righteous." (al-An'am: 153)

The Qur'an 5:105

"O ye who believe ! Guard your own souls : if ye follow (right) guidance, no hurt can come to you from those who stray. The goal 
of you all is to God : it is He that will show you the truth of all that ye do." (al-Maidah: 105).

(2) The prophet Tradition transmitted by Al Bukhari " there will be a Prophet after me" and another tradition of the Prophet transmitted by Tirmidzi "Messengership and prophet hood have been ended: for this reason there will not be a Messenger nor a Prophet after me Observing:

1. The Decision of the Majma' al-Figh al-Islami Organisasi Konferensi Islam (OKI) No. 4 (4/2) in its second conference in Jeddah, Saudi Arabia on 10-16 Rabi' al-Tsani 1406 AH/22-28 December 1985 on the Ahmadiyah Qadiyan doctrines in which amongst other things states that the Ahmadiyah doctrines which acknowledges Mirza Ghulam Ahmad as a Prophet after the Prophet Muhammad and that he has received divine revelation is apostasy and deviating from Islam since it disavows the definite Islamic doctrines which is acknowledged by all Ulama that the Prophet Muhammad is the last Prophet and Messenger.

The text of the decree is as follows:

"Truthfully, what is claimed by Mirza Ghulam Ahmad on his prophecy, the doctrines he carried and revelations descended on him are strict deviancy against the definite Islamic doctrines that the Prophet Muhammad is the last Messenger and Prophet; and that there would be no more revelations descended on anyone after this. The belief disseminated by Mirza Ghulam Ahmad has made him and his followers apostates, and deviating from Islam. The Ahmadiyah Qadian and the Ahmadiyah Lahore are the same, although the later (the Ahmadiyah Lahore) believes that Mirza Ghulam Ahmad is the shadow and the continuation of the Prophet Muhammad" 
2. The decree of the fatwa on the Council of Indonesian Ulama in the Second MUNAS in 1980 on the Ahmadiyah Qadiyan

3. The opinion of the Fatwa Commission assembly in the seventh MUNAS of the Council of Indonesian Ulama in 2005

with tawakkal to Allah

decide that and determine: Fatwa on the Ahmadiyah Doctrines

1. To affirm the decree of the fatwa of the Council of Indonesian ulama in the second conference in 1980 which decided that the Ahmadiyah doctrines is out of the path of Islam, heretical and deviating; and a Muslim who has joined this doctrines is an apostate

2. For those who joined the Ahmadiyah doctrines to return immediately to the true Islam which is in line with the Qur'an and the traditions of the Prophet

3. To oblige the government to ban the dissemination of Ahmadiyah doctrines throughout Indonesia and to annul the organization as well as to close all its offices.

Decreed in Jakarta, on 21 Jumadil Akhir 1426 H/ 28 July 2005M. and was signed by the chairman of the Fatwa Commission, K.H. Ma'ruf Amin, and the secretary. H. Hasanuddin, and also the chairman of the plenary meeting, Umar Shihab, and the secretary, H.M. Din Syamsuddin.

After reading the two fatwas of the MUI on Ahmadiyah, there are at least two conclusions to infer. First of all, the content of the fatwa in 2005 is an affirmation and combination between the fatwa issued in 1980 and a recommendation in 1984, which principally have the same substance that the Ahmadiyah community is out of Islam, heretical and deviated. Second, the fatwa issued in 2005 affirms that the government is obliged to ban the dissemination of the Ahmadiyah teachings throughout the territory of Indonesia. Furthermore, there are some differences between the fatwa issued in 1980 and in 2005. The former 
does not mention any reasons to show the deviation of the Ahmadiyah, whereas the later mentions a number of reasons both from the Holy al-Qur'an and the Prophet traditions. From this discussion, it is clear that the Ahmadiyah case is not something new but it is an old case which again becomes an issue.

The Ahmadiyah phenomenon evokes controversy among Indonesian Muslims. Many acknowledge its existence based on human rights. Conversely, many other Muslims, either individual or organization see that the Ahmadiyah teachings are not in line with Islamic teachings.

As a way out, the Ministry of Religious Affairs (Depag RI.) through the community guidance of Islam (Bimas Islam) established a monitoring team to oversee whether the Ahmadiyah community is consequent with the 12 points they have made or not. In line with this, Bakorpakem or the overseer of the people's belief (on Tuesday, 15 January 2008) gave an opportunity to the Ahmadiyah community in Indonesia to enact the 12 points of clarification on their teachings which prove that they are not deviant. ${ }^{8}$

But the clarification could not solve the problem. Many points of clarification are assumed to strengthen the indication that the Ahmadiyah is no longer in line with Islamic teachings. For instance, Ma'ruf Amin, the chairman of the Fatwa Commission of the MUI stated that the 12 points of clarification did not indicate that the Ahmadiyah has changed. Furthermore, he put forward the following statement 'you are what you were'. The same judgment came from the chairman of Dewan Dakwah Islam Indonesia (DDII), Adian Husaini. In his opinion, the 12 points of clarification are fake confession. Almost the same statement was given by Goodwill Zubairi, the secretary of PP Muhammadiyah. He said 'do not do lips service' . ${ }^{9}$ In addition, the general secretary of Forum Umat Islam (FUI), KH Muhammad al-Khaththath, considers that the establishment of the 12 points of clarification is full of political nuance. ${ }^{10}$

Points 1-3 of the 12 points of clarification show no difference between the old and the new Ahmadiyah and there is no clause which states or denies Mirza

\footnotetext{
${ }^{8}$ Republika, Sunday, 20 January 2008, p. 1.

9 Republika, Friday, 18 January 2008, p. 1.

${ }^{10}$ Republika, Sunday, 20 January 2008, p. 1.
} 
Ghulam Ahmad's prophecy. The fifth point indicates the belief on non-syariat revelation since it mentions the Holy Qur'an and the Prophet Traditions as syariat revelation. The sixth point indicates that tadzkirah is a holy revelation. ${ }^{11}$ As a note, these 12 points of clarification are the result of seven-round discussion between the Ministry of Religious Affairs (Litbang) and Jemaah Ahmadiyah Indonesia (JAI).

Meanwhile, the director of Lembaga Penelitian dan Pengkajian Islam (LPPI) Amin Jamaluddin during hearing meeting with the eighth commission of the People's Assembly in Jakarta, Monday (18 February 2008) delivered the result of his research on the content of Tadzkiroh, the holy book of the Ahmadiyah community. First, Ahmadiyah community considers Tadzkiroh as the divine revelation given to Mirza Ghulam Ahmad in India. There are 86 books compiled in Tadzkiroh. Second, this book contains many fragments of the verses of the Holy al-Qur'an. Third, in the belief of the Ahmadiyah community Syahadah Muhammad means Mirza Ghulam Ahmad. The third conclusion is strengthened by one of the verses of Tadzkiroh, If you want God's love so follow me, I am the messenger of God for all of you'. ${ }^{2}$

In line with the result of study of Amin Jamaluddin, Munarman, the attorney of Forum Umat Islam (FUI) once got an sms which was forwarded by Agus Miftah from Soekmana Soma, the spokesperson of Jemaah Ahmadiyah Indonesia (JAI), which reads as follow, 'Here are tips from me in order that the MUI and its allies declare JAI the loser, they should 1. be more knowledgable, 2. be of good character, 3 . be more patient. The history shows that faith has never been defeated by any fatwa, anarchy and court'. ${ }^{13}$

Therefore, based on this fact the second group including Front Umat Islam (FUI) constantly urges the government through the overseer of the people's belief (Bakorpakem) to ban the dissemination of the Ahmadiyah teachings. It is important to note that in 2005 Bakorpakem recommended the

\footnotetext{
${ }_{11}$ Republika, Friday, 18 January 2008, p. 1.

${ }_{12}$ Republika, Tuesday, 19 February 2008, p. 12.

${ }^{13}$ Republika, Tuesday, 19 February 2008, p. 12.
} 
government/president to ban Ahmadiyah teachings in a form of presidential decree (Perpres). ${ }^{14}$

Even the chairman of Muslim's attorney team (TPM) Mahenderatta has an intention to accuse the President of Indonesia as the most responsible person who gave the opportunity to Mirza Ghulam Ahmad's followers to disseminate their teachings in Indonesia. In his opinion, its dissemination should be banned since the MUI has decreed a fatwa declaring that Ahmadiyah is a heretical sect. The planning of the accusation which will be sent to many district courts, such as Bandung, Cianjur, Sukabumi, Semarang, Solo and Surabaya, however, receive no support from the attorney of Forum Umat Islam (FUI), Munarman.

About Tadzkiroh, Insan Budi Maulana, an advocate and professor at Krisnadwipayana University, as well as a lecturer at UI and IBII, concluded that if it is considered as a composition with copy right approach, then Mirza Ghulam Ahmad's work should not be distributed and published in Indonesia, since it is a blasphemy on Islam, a religion embraced by the majority people in Indonesia. The basis of this conclusion are article 17 of copy right ordinance (UUHC No. 7 year 1987), which is revised with UUHC No. 12 year 1997, and the last UUHC NO. 19 year 2002, states that the government ban any composition which is in contrast to the government's policy either in religion, national defense and security, ethics, and social order after hearing the considerations of the copy rights committee. Then in order to replace the copy right committee, asking the opinion of the MUI and reviewing Mirza's work are right. So if the MUI has reviewed the book very carefully and concluded that the content of the book is in line with the decision stated on article no. 17, the attorney general should not hesitate to ban the distribution, the copy and the announcement of Tadzkiroh. ${ }^{15}$

14 Republika, Saturday, 19 January 2008.

15 Insan Budi Maulana, "Tadzkiroh dan Pelarangan Buku”, Republika, Saturday, 16 February 2008, Opinion, p. 4. Almost at the same time, the Judge of the district Court (PN) of South Jakarta, Wednesday (13/2/08) accused the top leader of al-Qiyadah al-Islamiyah, Abdussalam alias Ahmad Moshadd for blasphemy. Moshaddeq proclaimed himself as a prophet after The Prophet Muhammad. One of his teachings is not obliging his follower to perform the five-time prayers, fasting during Ramadhan and Hajj. Risalah Moshoddeq began from his his hermitage in Mountain Bunder Bogor, West Java for 40 days and nights on June 2006. Then on 23 June 2006, he declared himself to be a messenger of God entitled al-Masih al-Mau'ud in front of 
In order to analyze the controversy on Ahmadiyah, theories on clustering Islamic teachings and on religion by Rudolf Otto as well as the approach on greater benefit (maslahah) are used. The following are short explanation on the analysis and the intended attitude.

By using the theory on clustering of Islamic teachings, it is explained that Islamic teachings can be divided into two including normative Islam and Historic Islam. Almost the same terms are used to replace the aforementioned terms consisting of Islam as revelation and Islam as a product of history. ${ }^{16}$ Islam as revelation is defined as follows:

This means:

"Divine revelation revealed to the Prophet Muhammad is meant for happiness in both on earth and the hereafter."

Meanwhile Historic Islam or Islam as a product of history is Islam which has been understood and practiced by Muslims throughout the world since the Prophet Muhammad era up today, either in Indonesia or in anywhere else.

In line with clustering Islam as normative and historic Islam, Nasr Hamid Abu Zaid defines Islam into three domains of research in Islam.

First is the domain of the original text of Islam (the Holy al-Qur'an and the authentic traditions of the Prophet Muhammad).

Second is Islamic thought in form of various interpretations on the authentic texts of Islam (al-Qur'an dan The Traditions of the Prophet Muhammad) or the result of ijtihad on the authentic Islamic texts, such as interpretation and fiqh. There are four branches under this categorization: (1) Islamic law/figh, (2) theology, (3) philosophy, and (4) mysticism. The result of ijtihad in Islamic laws is in the forms of: (1) fiqh, (2) fatwa, (3) jurisprudence (the compilation of verdicts), (4) regulations, (5) codification, and (6) compilation.

54 people of his followers. The first meeting with 141 followers was held on 19/10/07 in Bintaro, the second meeting with 103 followers was held on 20/10/07 in BPPT, the third meeting with 125 followers was held on 21/10/07 in Sofyan Hotel, the fourth meeting with 278 followers was held on 22/10/07, in Graha BIP, the fifth meeting with 189 followers was held on 23/10/07 in Maharaja Hotel, and the last meeting with 160 followers was held in Wisma Tani Ragunan. Republika, Thursday, 14/2/08, p. 2.

${ }^{16}$ H. M. Atho Mudzhar, Pendekatan Studi Islam dalam Teori dan Praktik, (Yogyakarta: Pustaka Pelajar, 1998), pp. 19-22. 
Third is religious practices performed by Muslims with various social backgrounds. ${ }^{17}$ For instance, Pakistani Muslims do not put their hands on chest while performing prayers whereas the Indonesian Muslims do. Besides, Indonesian Muslims perform 'tahiyat akhir' by leaning to right while other Muslims do not perform it in the same way, and there are many other examples.

Abdullah Saeed mentions three levels with different formulations. The first level is basic value, belief, ideal, and institution. The second level is interpretation on the basic value in order to be implemented. The third level is the manifestation based on the basic values which differ among countries or even regions. This difference is caused by the distinctive context and culture.

In the first level, there are significant agreements among Muslims such as the oneness of God, Muhammad as the Messenger of God, The Holy al-Qur'an is the divine revelation from God, and that performing the five-time prayers a day, fasting during Ramadhan, paying alms, performing Hajj for those who are able to perform are obliged and that drinking alcohol and prostitution are forbidden.

In the second level, there are various distinctive opinions among Muslims, such as things to nullify ablution. Many ulama argue that physical contact between mature man and woman, excluding the elderly, nullify ablution. Some other ulama argue that physical contact which nullifies ablution is sexual intercourse between man and woman (jima').

In the third level Abdullah Saeed gives an example of the distinctive colors and fashions used during prayers, ${ }^{18}$ among Muslims throughout the world. Other examples of the fundamental teachings of Islam according to Abdullah Saeed are: (1) the acknowledgement of the oneness of God, and (2) the establishment of economy and social justice. ${ }^{19}$

Based on the above theory on clustering Islamic teachings, it is concluded that Muhammad's prophecy and His position as the last messenger have become the Muslims' fundamental belief. So, the reason why a group of Muslims oppose

\footnotetext{
${ }^{17}$ Nasr Abu Zaid, "The Textuality of the Koran", Islam and Europe in Past and present, by W. R. Hugenkoltz and K. van Vliet-leigh (eds.), (Wassenaar: NIAS, 1997), p. 43.

${ }^{18}$ Abdullah Saeed, Islam in Australia, (Crows West: Allen \& Unwin, 2003), pp. 65-67.

${ }^{19}$ Ibid., p. 20.
} 
and consider Ahmadiyah as heretical sect is that it does not in line with the acknowledged fundamental belief. Therefore, it is no exageration to say that Ahmadiyah will never get any acknowledgement from Muslims and will constantly receive opposition as long as they acknowledge Mirza Ghulam Ahmad as a prophet after the Prophet Muhammad.

Basically, the ten criteria decreed by the MUI as heretical sects explain the teachings which become the Muslims' fundamental belief as formulated by the experts above. Those ten criteria are:

1. Deny the principles of faith (rukun iman) and the principles of Islam (rukun Islam).

2. Believe or follow a certain belief which is not in line with Qur'an and the Prophet tradition.

3. Believe in the revelation after the Qur'an.

4. Deny the authenticity and the truth of the content of the Qur'an.

5. Interpret the Qur'an without depending on the principle of the interpretation of the Qur' an.

6. Deny the position of the Prophet tradition as the source of Islamic doctrines.

7. Underestimate the messengers and the prophets.

8. Deny the Prophet Muhammad as the last messenger and the last prophet.

9. Change the principles of the ibadah which determined by Islamic law.

10. Consider other Muslims as apostate without giving argument from either the Qur'an and the Prophet traditions (dalil syar'i).

So, a great offer for the Ahmadiyah in order not to be denied is to declare a new religion outside of Islam. This offer has been proposed for a quiet long time by Sir Muhammad Iqbal, and also the Minister of Religious Affairs of Indonesia Maftuh Basuni.

Citing Ahmad Khoirul Fata, by declaring Ahmadiyah as a new religion, there would not be many obstacles when religion is defined as an experience of the existence of supra-natural entity (numen) manifesting as mysterium 
tremendum as it is defined by Rudolf Otto. According to Him, the establishment of Ahmadiyah as a new religion outside of Islam can epistemologically be acknowledged since Ahmadiyah is based on the experience of its founder, Mirza Ghulam Ahmad. ${ }^{20}$

However, to response these differing opinions there should not be anarchy and threat on the right to live. One of the opinions is handing the case to the authority to solve the problem. Another way is avoiding any kinds of anarchy; both physically or psychic.

\section{Conclusion}

There are at least three points inferred from the above discussion. First, the content of the fatwa on banning the Ahmadiyah accommodates the belief of the majority Muslims in Indonesia. Second, the fatwa on Ahmadiyah decreed in 2005 is an affirmation on the decreed fatwa in 1980, and a recommendation issued in 1984. Third, it is no exaggeration to say that the best way for the Ahmadiyah community to avoid Muslims' mass violence is declaring a new religion out of Islam. Besides, it is suggested to refer the Ahmadiyah case to the authority and to avoid anarchy.

\section{BIBLIOGRAPHY}

Abdullah Saeed . 2003. Islam in Australia. Crows West: Allen \& Unwin.

Mohmmad Atho Mudzhar. 1998. Pendekatan Studi Islam dalam Teori dan Praktek. Yogyakarta: Pustaka Pelajar.

. 1993. Fatwa-fatwa Mejelis Ulama Indonesia: Sebuah Studi tentang Pemikiran Hukum Islam di Indonesia, 1975-1988, Ed. dwibahasa. Jakarta: INIS.

Nasr Abu Zaid. 1997. "The Textuality of the Koran”, Islam and Europe in Past and present, by W. R. Hugenkoltz and K. van Vliet-leigh (eds.),. Wassenaar: NIAS.

Tim Penyunting Majelis Ulama Indonesia. 1997. Himpunan Fatwa Majelis Ulama Indonesia. Jakarta: MUI.

${ }^{20}$ Ahmad Khoirul Fata, "Soft Violence Ahmadiyah”, Jawa Pos, Friday 11 January 2008, Opinion, p. 4. 
Tim MUI. 2005. Fatwa MUNAS VII Majelis Ulama Indonesia. Jakarta: MUI.

Sekretatiat MUI. t.t. Himpunan Keputusan dan Fatwa Majelis Ulama Indonesia. Jakarta: Sekretariat MUI.

Insan Budi Maulana. 2008. "Tadzkiroh dan Pelarangan Buku”, in Republika, 16 February 2008.

Ahmad Khoirul Fata. 2008. "Soft Violence Ahmadiyah", in Jawa Pos, 11 January 2008 .

Jawa Pos. 2008. 11 January.

Jawa Pos. 2008. 10 January.

Republika. 2008. 18 January.

Republika. 2008. 19 January.

Republika. 2008. 20 January.

Republika. 2008. 14 February.

Republika. 2008. 16 February. 